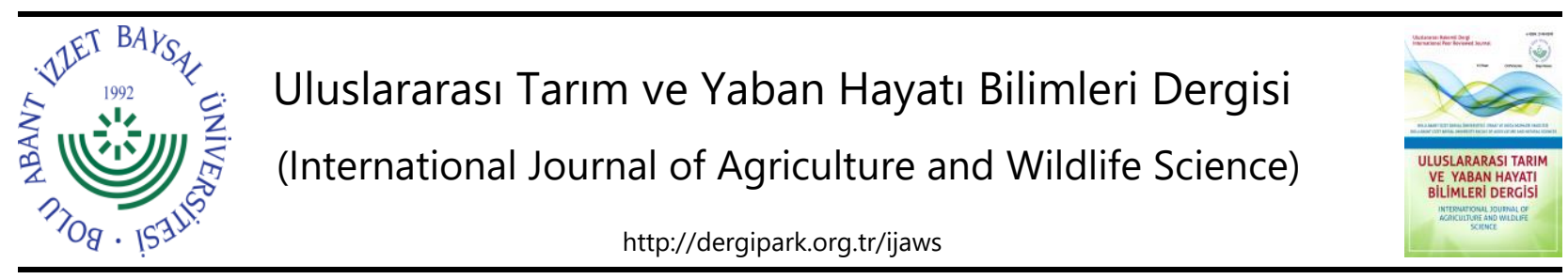

Araştırma Makalesi

\title{
Ülkemizde Yetiştirilen Önemli Fasulye Çeşitlerinin Pas (Uromyces appendiculatus) ve Adi Yaprak Yanıklığı (Xanthomonas axonopodis pv. phaseoli) Hastalıklarına Karşı Dayanıklııı Kaynakları Açısından Değerlendirilmesi
}

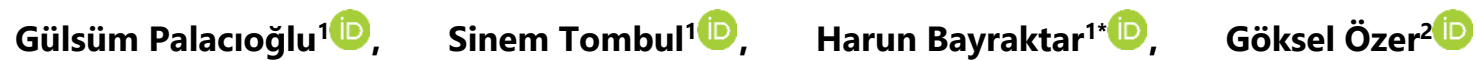 \\ ${ }^{1}$ Ankara Üniversitesi, Ziraat Fakültesi, Bitki Koruma Bölümü, Ankara \\ ${ }^{2}$ Bolu Abant İzzet Baysal Üniversitesi, Ziraat Fakültesi, Bitki Koruma Bölümü, Bolu \\ Geliş tarihi (Received): 19.02.2021 Kabul tarihi (Accepted): 20.05.2021
}

\begin{abstract}
Anahtar kelimeler:
Adi yaprak yanıklığı, fasulye, dayanıklılık kaynağı, moleküler markör, pas

*Sorumlu yazar bayrakta@agri.ankara.edu.tr

Özet. Fasulye pası Uromyces appendiculatus ve adi yaprak yanıklığı etmeni Xanthomonas axonopodis pv. phaseoli dünya genelinde fasulye üretim alanlarında yaygın olarak görülen önemli hastalık etmenleridir. Bu hastalık etmenleriyle en etkin ve sürdürülebilir mücadele yöntemi dayanıklı ıslah materyallerinin geliştirilmesidir. Bu amaçla yapılan çalışmalarda söz konusu hastalıklara karşı dayanıklılıkta rol oynayan lokuslar ile ilişkili birçok moleküler markör geliştirilmiş ve ıslah çalışmalarına dâhil edilmiştir. Bu çalışma kapsamında ise ülkemizde yaygın olarak yetiştirilen 40 adet fasulye çeşidi, pas ve adi yaprak yanıklığı hastalıklarına karşı taşıdıkları dayanıklıık kaynakları bakımından SCAR markörleri (SAE19, SI19, SA14, SBC6, SAP6, SU91, BC420) aracılı̆̆ıyla incelenmiştir. $U$. appendiculatus'a karşı dayanıklılıkla ilişkili Ur-11 ve Ur-4 lokuslarının çeşitler arasında oldukça yaygın olduğu görülürken, $X$. axonopodis pv. phaseoli'ye karşı sadece Boncuk, Belinay Sırık, Sırık barbunya, Zülbiye ve Bulduk çeşitlerinin B10 lokusu taşıdığı gözlenmiştir. Çalışma kapsamında tespit edilen bu dayanıklılık lokuslarının fasulye pası ve adi yaprak yanıklığı hastalıklarına karşı ıslah materyallerinin geliştirilmesinde ve gen piramitleme çalışmalarında potansiyel dayanıklıık kaynakları olarak dikkate alınması faydalı olacaktır.
\end{abstract}

\section{Evaluation for Resistance Sources of Common Bean Cultivars Grown in Turkey to Rust (Uromyces appendiculatus) and Common Bacterial Blight (Xanthomonas axonopodis pv. phaseoli) Diseases}

\section{Keywords:}

Common bacterial blight, common bean, resistance resources, molecular marker, rust.

\begin{abstract}
Bean rust caused by Uromyces appendiculatus and common bacterial blight by Xanthomonas axonopodis pv. phaseoli are among the important diseases that widely occur in bean production areas worldwide. The most effective and sustainable control method against these disease is the development of resistant breeding materials. Many molecular markers associated with the loci that play a role in resistance against these diseases have been developed and integrated in breeding programs. In this study, 40 common bean cultivars widely grown in Turkey were screened molecularly for resistance sources against bean rust and common bacterial blight diseases using SCAR markers (SAE19, SI19, SA14, SBC6, SAP6, SU91, and BC420). The loci of Ur-11 and Ur-4 associated with resistance against $U$. appendiculatus were very common among common bean cultivars, while B10 resistance locus against $X$. axonopodis pv. phaseoli was determined in only Boncuk, Belinay Sırık, Sırık Barbunya, Zülbiye and Bulduk cultivars from common bean cultivars tested. These resistance loci determined in this study should be considered as candidate resistance sources in the development of breeding materials and gene pyramiding studies against rust and common bacterial blight disease of common bean.
\end{abstract}




\section{GíRiş}

Baklagiller arasında yer alan fasulye (Phaseolus vulgaris L.) bitkisi insan beslenmesi için önemli bir protein kaynağı olup Latin Amerika, Asya ve Afrika ülkelerinde yaygın olarak üretilmektedir (Broughton ve ark., 2003; Yeken ve ark., 2018). Ülkemizde hemen her bölgede fasulye üretimi gerçekleştirilmekle birlikte taze fasulye için en fazla üretim Karadeniz bölgesinde; kuru fasulye için ise iç Anadolu bölgesinde yapılmaktadır (TUiK, 2019). Dünyada önemli bir fasulye üreticisi konumunda olan ülkemiz, 596.074 ton ile taze fasulyede 5. sırada, 225.000 ton kuru fasulye üretimi ile de 22. sırada yer almaktadır (FAOSTAT, 2020). Ancak dünyada ve ülkemizde fasulye üretimini kısıtlayan çok sayıda fungal, bakteriyel ve viral hastalık etmeni bulunmaktadır (Hall, 1994). Fungal hastalık etmenleri arasında Uromyces appendiculatus'un neden olduğu pas hastalığı ile bakteriyel etmen Xanthomonas axonopodis pv. phaseoli'nin neden olduğu adi yaprak yanıklı̆ı dünyada fasulye üretim alanlarında yaygın olarak görülen hastalık etmenlerindendir (Araya ve ark., 2004; Tugume ve ark., 2019).

Uromyces appendiculatus'un neden olduğu pas hastalığı, fasulye bitkisinin tüm toprak üstü aksamını etkilemesine rağmen daha çok yapraklarda enfeksiyon oluşturmaktadır. Etmen yaprak ve kapsüller üzerinde kırmızımsı kahverengi, 1-2 mm çapında, dairesel üredial püstüller oluşturmakta ve bu püstüllerin etrafı sarı bir hale ile çevrilmektedir (Hall, 1994). Uygun iklim koşullarında, erken ve şiddetli enfeksiyonlarda \%100'e varan verim kaybına neden olmaktadır (Lindgren ve ark., 1995; Souza ve ark., 2008). Etmen, fungal patojenler arasında en yüksek patojenik ve genetik varyasyon gösteren türlerden bir tanesi olup dünyada 300'den fazla ırkı tespit edilmiştir (Araya ve ark., 2004). Fasulye çeşitlerinin çoğu belirli patojen ırklarına karşı dayanıklı olmasına rağmen sadece birkaçı çok sayıda ırka dayanıklııı göstermektedir (Souza ve ark., 2013). Pas hastalığı ile mücadelede ürün rotasyonu, enfekte olan bitki artıklarının yok edilmesi gibi kültürel önlemlerin yanı sıra fungisit uygulamaları yaygın olarak kullanılmaktadır (Hall, 1994). Ancak bu hastalığa karşı en etkili ve ekonomik mücadele yönteminin dayanıkı fasulye çeşitlerinin kullanımı olduğu bilinmektedir (Faleiro ve ark., 2000; Alzate-Marin ve ark., 2004).

Fasulye pasına karşı dayanıkııık, genellikle tek bir dominant gen tarafından yönetilmekle birlikte tek resesif bir gen, iki dominant genin birleşimi veya çok sayıda genin etkileşimi hastalık kontrolünde önemli fayda sağlamaktadır (Zaiter ve ark., 1989; Grafton ve ark., 1985; Edington ve ark., 1994; Alzate-Marin ve ark., 2004; Souza ve ark., 2007a, 2007b). Patojenin çok sayıda ırkına karşı etkin dayanıklılık oluşumu gen lokuslarının birleşimi ve kümelenmesi ile düzenlenebilmektedir (Stavely ve Grafton, 1985). Şimdiye kadar, fasulye genomunda pas etmenine karşı dayanıklııkla ilişkili 14 major dominant gen (Ur-1, Ur-2, Ur-3,Ur-4, Ur-5, Ur-6, Ur-7, Ur-8, Ur-9, Ur10, Ur-11, Ur-12, Ur-13, Ur-14) ile Montcalm, Dorado, BAC6, CNC ve PI 260418 gibi isimlendirilmemiş RR genleri tanımlanmıştır (McClean ve Myers, 1990; Jung ve ark., 1996; Miklas ve ark., 2000, 2002; Rasmussen ve ark., 2002; Pastor-Corrales, 2005; Liebenberg ve ark., 2006; Pastor-Corrales ve ark., 2008). Ayrıca bu gen kaynakları ile ilişkili bazı RAPD ve SCAR markörler geliştirilmiş olup Ur genlerinin haritalanması için yaygın olarak kullanılmaktadır (Freyre ve ark., 1998; Miklas ve ark., 2002; Kelly ve ark., 2003; Miklas ve ark., 2006). Ülkemizde ise fasulye çeşitlerinin etmene karşı reaksiyonları klasik yöntemlerle araştırılmasına rağmen dayanıklıık kaynaklarını tespit etmek amacıyla oldukça az sayıda çalışma gerçekleştirilmiştir (Altıkardeşler ve Arslan, 2007; Yeken ve ark., 2019).

Xanthomonas axonopodis pv. phaseoli'nin neden olduğu adi yaprak yanıklığı hastalığı ise dünyada fasulye üretilen tüm alanlarda yaygın olarak görülmekte ve üründe önemli verim ve kalite kayıplarına neden olmaktadır (Hall, 1994; Gillard ve ark., 2009). Gram negatif ve aerobik bir bakteri olan X. axonopodis pv. phaseoli, fasulyenin pek çok türünde enfeksiyon yapabilmektedir. Bitkinin yapraklarında suyla ıslatılmış gibi, sarkık, zamanla genişleyen nekrotik lekeler meydana gelmektedir. Bu lezyonlar genellikle yaprakların damarları arasında veya kenarlarında bulunmakta ve büyüdükçe yanık bir görünüme dönüşmektedir. Kapsüller üzerinde ise boyutu kapsülün büyüklüğüne ve olgunluğuna göre değişmekle birlikte dairesel, hafif çökük, koyu kırmızımsı-kahverengi lezyonlar oluşturmaktadır. Uygun iklim koşullarında kapsüller üzerindeki lezyonlarda çoğunlukla bakteriyel sızıntılar gözlenmektedir. Enfekteli tohumlarda şekil bozuklukları meydana gelmekte ve çimlenme yetenekleri kaybolmaktadır (Hall, 1994). Bu nedenle etmenle mücadelede hastalıktan ari sertifikalı tohum kullanımı, tohumların antibiyotikle muamele edilmesi, uzun süreli ürün rotasyonları ve bakırlı preparatların kullanımı tavsiye edilmektedir (Mutlu ve ark., 2005). Ancak bu yöntemlerin uzun zaman alması, maliyetlerinin yüksek olması ve çevreye olan etkileri göz önüne alındığında en etkili ve sürdürülebilir mücadele yönteminin dayanıklı çeşitlerin geliştirilmesi ve kullanımı olduğu görülmektedir (Gillard ve ark., 2009). Bu kapsamda X. axonopodis pv. phaseoli'ye karşı dayanıklılıkla ilişkili genlerin tespitinde faydalı olan 6 farklı (SAP6, BAC6, SU91, BC420, R7313, R486) markör tespit edilmiş ve farklı araştırııılar tarafından kullanılmıştır (Pedraza ve ark., 1997; Miklas ve ark., 2000; Yu ve ark., 2000). Ülkemizde yapılan çalışmalarda ise fasulye çeşitlerinin mevcut dayanıklıık kaynaklarını ortaya koyan oldukça az sayıda çalışma bulunmaktadır (Dursun ve ark., 2002; Poyraz ve ark., 2017). Bu çalışma kapsamında önemli bir fasulye üreticisi olan ülkemizde yaygın olarak yetiştirilen 40 fasulye çeşidindeki $U$. appendiculatus ve $X$. 
Palacıoğlu ve ark., Ülkemizde Yetiştirilen Önemli Fasulye Çeşitlerinin Pas (Uromyces appendiculatus) ve Adi Yaprak Yanıklığı (Xanthomonas axonopodis pv. phaseoli) Hastalıklarına Karşı Dayanıklılık Kaynakları Açısından Değerlendirilmesi

axonopodis pv. phaseoli'ye karşı farklı dayanıklılık kaynaklarının moleküler markörler aracılığıyla tespit edilmesi ve ıslah çalışmalarında kullanılabilecek potansiyel genetik kaynakların belirlenmesi amaçlanmıştır.

\section{MATERYAL VE METOT}

\section{Fasulye Bitkilerin Yetiştirilmesi}

Çalışmada ülkemizde yaygın olarak yetiştirilen ve farklı kaynaklardan elde edilen 24'ü taze, 6'sı barbunya ve 10 adedi kuru fasulye olmak üzere toplam 40 fasulye çeşidi kullanılmıştır (Çizelge 1). Aynı zamanda USDA'dan (United States Department of Agriculture Research Service, $A B D$ ) elde edilen ve ilgili dayanıklılık genlerini taşıdığı bilinen bazı referans genotipler (Ouro negro, Cornell, To, Widusa) de çalışmaya dâhil edilmiştir. Tohumlar ekimden önce yüzeysel dezenfeksiyon amacıyla \%1'lik sodyumhipoklorit ( $\mathrm{NaOCl}$ ) içeren solüsyonda 2 dakika tutulmuş ve bunu takiben 3 seri steril saf sudan geçirilerek steril toprak, kum, gübre karışımı içeren $(1: 1: 1 \mathrm{v} / \mathrm{v}) 16 \mathrm{~cm}$ çapındaki saksılara ekilmiştir. Bitkiler $23^{\circ} \mathrm{C}$ sıcaklık ve $14 / 10$ saatlik ışık periyodu içeren kontrollü koşullardaki bitki yetiştirme odasında 10 gün süreyle yetiştirilmiştir. Daha sonra gelişen bitkilerin ilk kotiledon yapraklarından örnekler alınarak SıVı nitrojen içerisinde dondurulmuş ve kullanılana kadar $-80^{\circ} \mathrm{C}^{\prime}$ de saklanmıştır.

\section{Bitki Dokusundan DNA Ekstraksiyonu}

Bitki örneklerinden genomik DNA ekstraksiyonu DArT DNA izolasyon yöntemi (http://www.diversityarrays.com) kullanılarak gerçekleştirilmiştir. Her fasulye çeşidinin yapraklarından yaklaşık 100 mg donmuş bitki dokusu alınarak $1 \mathrm{~mL}$ ekstraksiyon tamponu (125 mM Tris-HCl pH 8, $25 \mathrm{mM}$ EDTA pH 8, $0.8 \mathrm{M}$ $\mathrm{NaCl}$ \% \% $1 \mathrm{CTAB}$, \%1 sarcosyl, \%2 PVP-40 (K29-32), \%0.5 sodyum disulfit) içerisinde homojenize edilmiş ve $65^{\circ} \mathrm{C}^{\prime}$ de 1 saat inkübasyona bırakılmıştır. Ardından örneklere eşit hacimde kloroform-isoamilalkol (24:1) karışımı eklenerek iyice karıştııımış ve 10.000 g'de 20 dakika santrifüj edilmiştir. Üst sıvı temiz Eppendorf tüplere alınarak eşit hacimde soğuk isopropanol eklenmiş ve $-20^{\circ} \mathrm{C}$ 'de bekletilmiştir. Karışım $10.000 \mathrm{~g}$ 'de 5 dakika santrifüj edildikten sonra üst sıvı dökülmüş ve DNA pelleti $500 \mu \mathrm{L} \% 70^{\prime}$ lik soğuk etanol ile yıkanmıştır. Oda koşullarında kurutulduktan sonra DNA pelleti $100 \mu \mathrm{L}$ steril su ile çözülmüştür. DNA konsantrasyon ve kalitesi spektrofotometrik olarak 260/280 nm'de ölçüm yapılarak belirlenmiş ve tüm DNA örnekleri $20 \mathrm{ng} / \mu \mathrm{L}$ olacak şekilde seyreltilerek $-20^{\circ} \mathrm{C}^{\prime}$ de saklanmıştır.

\section{Fasulye Çeşitlerine Ait Dayanıklılık Kaynaklarının Moleküler Markörler ile Tespiti}

Fasulye çeşitlerinin taşıdıkları dayanıklıık genleri fasulye pası ile ilişkili 4 (SA14, SI19, SBC6, SAE19) markör ve adi yaprak yanıklığı hastalığı ile ilişkili 3 farklı SCAR (BC420, SU91, SAP6) markörü ile araştırılmıştır (Çizelge 2). PCR reaksiyonları $0.2 \mu \mathrm{M}$ dNTPs, $0.3 \mu \mathrm{M}$ primer, $1.5 \mathrm{mM} \mathrm{MgCl}$, 10x PCR buffer, 20 ng DNA, 1U Taq DNA polimeraz içeren $25 \mu$ l'lik hacimlerde gerçekleştirilmiştir. Her primer için PCR amplifikasyonları Çizelge 2'de belirtilen protokoller kullanılarak gerçekleştirmiştir. Elde edilen PCR ürünleri \%1.2'lik agaroz jelde 100 V'da elektroforetik olarak ayrılarak gözlenmiş ve beklenilen PCR ürünlerinin büyüklükleri GeneRuler 100 bp DNA ladder (Thermo Scientific, ABD) kullanılarak tespit edilmiştir. Ayrıca dayanıkııık genleri ile ilişkili amplifikasyon ürünlerinin varlığı referans çeşitler ile kıyaslanarak var (+), yok (-) olarak doğrulanmıştır.

Çizelge 1. Test edilen fasulye çeşitlerinin özellikleri ve hastalık etmenlerine karşı taşıdıkları dayanıklıık kaynakları. Table 1. Characteristics of common bean cultivars tested and resistance sources of these cultivars against disease agents.

\begin{tabular}{|c|c|c|c|c|c|c|}
\hline \multirow{2}{*}{ Çeşit ismi } & \multirow{2}{*}{ Fasulye tipi } & \multirow{2}{*}{$\begin{array}{l}\text { Elde edildiği } \\
\text { kurum }\end{array}$} & \multicolumn{3}{|c|}{ Pas hastalığı } & \multirow{2}{*}{$\begin{array}{l}\text { Adi yaprak } \\
\text { yanıklığı } \\
\text { SAP6/ } \\
\text { B10 }\end{array}$} \\
\hline & & & $\begin{array}{l}\text { SA14/ } \\
\text { Ur-4 }\end{array}$ & $\begin{array}{l}\text { SI19/ } \\
\text { Ur-5 }\end{array}$ & $\begin{array}{l}\text { SAE19/ } \\
\text { Ur-11 }\end{array}$ & \\
\hline Seher yıldızı & Taze & $\begin{array}{l}\text { Karadeniz Tar. } \\
\text { Arş. Enst. }\end{array}$ & + & - & + & - \\
\hline Zeynebim & Taze & $\begin{array}{l}\text { Karadeniz Tar. } \\
\text { Arş. Enst. }\end{array}$ & + & - & + & - \\
\hline Boncuk & Taze & $\begin{array}{l}\text { Geçit Kuşağı Tar. } \\
\text { Arş. Enst. }\end{array}$ & + & - & + & + \\
\hline Fransız & Taze & $\begin{array}{l}\text { Geçit Kuşağı Tar. } \\
\text { Arş. Enst. }\end{array}$ & + & - & + & - \\
\hline 40 Günlük & Taze & $\begin{array}{l}\text { Geçit Kuşağı Tar. } \\
\text { Arş. Enst. }\end{array}$ & + & - & + & - \\
\hline Karabacak & Taze & $\begin{array}{l}\text { Geçit Kuşağı Tar. } \\
\text { Arş. Enst. }\end{array}$ & + & - & + & - \\
\hline
\end{tabular}




\section{Çizelge 1. Devamı.}

Table 1. Continue.

\begin{tabular}{|c|c|c|c|c|c|c|}
\hline \multirow{2}{*}{ Çeşit ismi } & \multirow{2}{*}{ Fasulye tipi } & \multirow{2}{*}{$\begin{array}{l}\text { Elde edildiği } \\
\text { kurum }\end{array}$} & \multicolumn{3}{|c|}{ Pas hastalığı } & \multirow{2}{*}{$\begin{array}{l}\text { Adi yaprak } \\
\text { yanıklığı }\end{array}$} \\
\hline & & & $\begin{array}{l}\text { SA14/ } \\
\text { Ur-4 }\end{array}$ & $\begin{array}{l}\text { SI19/ } \\
\text { Ur-5 }\end{array}$ & $\begin{array}{l}\text { SAE19/ } \\
\text { Ur-11 }\end{array}$ & \\
\hline Sazova & Taze & $\begin{array}{l}\text { Geçit Kuşağı Tar. } \\
\text { Arş. Enst. }\end{array}$ & + & - & + & - \\
\hline Gina & Taze & May Tohum & + & - & + & - \\
\hline Magnum & Taze & May Tohum & + & - & + & - \\
\hline Java & Taze & May Tohum & + & - & + & - \\
\hline Asya & Taze & May Tohum & + & - & + & - \\
\hline Sofia & Taze & May Tohum & - & - & + & - \\
\hline Volare & Taze & May Tohum & + & - & + & - \\
\hline Özayşe & Taze & $\begin{array}{l}\text { Batı Akdeniz Tar. } \\
\text { Arş. Enst. }\end{array}$ & + & - & + & - \\
\hline Yalova 5 & Taze & $\begin{array}{l}\text { Atatürk Bahçe } \\
\text { Kültürleri Arş. } \\
\text { Enst. }\end{array}$ & + & - & + & - \\
\hline Yalova 17 & Taze & $\begin{array}{l}\text { Atatürk Bahçe } \\
\text { Kültürleri Arş. } \\
\text { Enst. }\end{array}$ & + & - & + & - \\
\hline Perolar & Taze & $\begin{array}{l}\text { Makrogen } \\
\text { Tohumculuk }\end{array}$ & - & - & + & - \\
\hline Sarıkız & Taze & $\begin{array}{l}\text { Makrogen } \\
\text { Tohumculuk }\end{array}$ & + & - & + & - \\
\hline Mina & Taze & $\begin{array}{l}\text { Makrogen } \\
\text { Tohumculuk }\end{array}$ & + & - & + & - \\
\hline Gelincik & Taze & $\begin{array}{l}\text { Makrogen } \\
\text { Tohumculuk }\end{array}$ & + & - & + & - \\
\hline Tavil & Taze & $\begin{array}{l}\text { Makrogen } \\
\text { Tohumculuk }\end{array}$ & + & - & + & - \\
\hline Nazende & Taze & $\begin{array}{l}\text { Makrogen } \\
\text { Tohumculuk }\end{array}$ & + & - & + & - \\
\hline Miray & Taze & $\begin{array}{l}\text { Sim Arzuman } \\
\text { Tarım Ürünleri }\end{array}$ & + & - & + & - \\
\hline Hanımteni & Taze & $\begin{array}{l}\text { Sim Arzuman } \\
\text { Tarım Ürünleri }\end{array}$ & + & - & + & - \\
\hline Selim & Barbunya & $\begin{array}{l}\text { Sim Arzuman } \\
\text { Tarım Ürünleri }\end{array}$ & + & - & + & - \\
\hline Sırık barbunya & Barbunya & Poltar Tarım & + & - & + & + \\
\hline Klas barbunya & Barbunya & Poltar Tarım & + & - & + & - \\
\hline Buse Oturak & Barbunya & $\begin{array}{l}\text { Makrogen } \\
\text { Tohumculuk }\end{array}$ & + & - & + & - \\
\hline Belinay Sırık & Barbunya & $\begin{array}{l}\text { Makrogen } \\
\text { Tohumculuk }\end{array}$ & + & - & + & + \\
\hline Sembol & Barbunya & $\begin{array}{l}\text { Makrogen } \\
\text { Tohumculuk }\end{array}$ & + & - & + & - \\
\hline Zülbiye & Kuru & $\begin{array}{l}\text { Karadeniz Tar. } \\
\text { Arş. Enst. }\end{array}$ & + & - & + & + \\
\hline Akdağ & Kuru & $\begin{array}{l}\text { Geçit Kuşağı Tar. } \\
\text { Arş. Enst. }\end{array}$ & - & - & + & - \\
\hline Akın & Kuru & $\begin{array}{l}\text { Geçit Kuşağı Tar. } \\
\text { Arş. Enst. }\end{array}$ & + & - & + & - \\
\hline Önceler & Kuru & $\begin{array}{l}\text { Geçit Kuşağı Tar. } \\
\text { Arş. Enst. }\end{array}$ & + & - & + & - \\
\hline Karacaşehir90 & Kuru & $\begin{array}{l}\text { Geçit Kuşağı Tar. } \\
\text { Arş. Enst. }\end{array}$ & + & - & + & - \\
\hline Göynük 98 & Kuru & $\begin{array}{l}\text { Geçit Kuşağı Tar. } \\
\text { Arş. Enst. }\end{array}$ & + & - & + & - \\
\hline
\end{tabular}




\begin{tabular}{|c|c|c|c|c|c|c|}
\hline \multirow{2}{*}{ Çeşit ismi } & \multirow{2}{*}{ Fasulye tipi } & \multirow{2}{*}{$\begin{array}{l}\text { Elde edildiği } \\
\text { kurum }\end{array}$} & \multicolumn{3}{|c|}{ Pas hastalığı } & \multirow{2}{*}{$\begin{array}{l}\text { Adi yaprak } \\
\text { yanıklığı } \\
\text { SAP6/ } \\
\text { B10 }\end{array}$} \\
\hline & & & $\begin{array}{l}\text { SA14/ } \\
\text { Ur-4 }\end{array}$ & $\begin{array}{l}\text { SI19/ } \\
\text { Ur-5 }\end{array}$ & $\begin{array}{l}\text { SAE19/ } \\
\text { Ur-11 }\end{array}$ & \\
\hline Bulduk & Kuru & $\begin{array}{l}\text { Geçit Kuşağı Tar. } \\
\text { Arş. Enst. }\end{array}$ & + & - & + & + \\
\hline Mecidiye & Kuru & $\begin{array}{l}\text { Doğu Anadolu } \\
\text { Tar. Arş. Enst. }\end{array}$ & + & - & + & - \\
\hline Aras & Kuru & $\begin{array}{l}\text { Doğu Anadolu } \\
\text { Tar. Arş. Enst. }\end{array}$ & + & - & + & - \\
\hline Yakutiye & Kuru & $\begin{array}{l}\text { Doğu Anadolu } \\
\text { Tar. Arş. Enst. }\end{array}$ & + & - & + & - \\
\hline
\end{tabular}

Çizelge 2. Fasulye çeşitlerindeki dayanıklılık genlerinin tespitinde kullanılan markörler ve PCR koşulları. Table 2. Molecular markers and PCR conditions used for determining resistance genes of common bean cultivars.

\begin{tabular}{|c|c|c|c|c|c|}
\hline Hastalık etmeni & $\begin{array}{l}\text { Primer/ } \\
\text { Gen Lokusu }\end{array}$ & Baz çifti & $\begin{array}{l}\text { PCR ürünü } \\
\text { (bp) }\end{array}$ & PCR koşulları & Literatür \\
\hline \multirow{3}{*}{$\begin{array}{l}\text { X. axonopodis } \\
\text { pv. phaseoli }\end{array}$} & SAP6/B10 & $\begin{array}{l}\text { 5'- GTCACGTCTCCTTAATAGTA-3' } \\
\text { 5'- GTCACGTCTCAATAGGCAAA-3' }\end{array}$ & 820 & $\begin{array}{l}94^{\circ} \mathrm{C} 10 \mathrm{~s}, 55^{\circ} \mathrm{C} 40 \mathrm{~s}, \text { ve } \\
72^{\circ} \mathrm{C} 120 \mathrm{~s} 34 \text { döngü } \\
\text { ve } 72^{\circ} \mathrm{C} 5 \mathrm{dk}\end{array}$ & $\begin{array}{l}\text { Miklas ve ark. } \\
2000\end{array}$ \\
\hline & BC420/B6 & $\begin{array}{l}\text { 5'-GCAGGGTTCGAAGACACACTGG-3' } \\
\text { 5'-GCAGGGTTCGCCCAATAACG-3' }\end{array}$ & 900 & $\begin{array}{l}94^{\circ} \mathrm{C} 30 \mathrm{~s}, 50^{\circ} \mathrm{C} 30 \mathrm{~s} \\
72^{\circ} \mathrm{C} 60 \mathrm{~s} 35 \text { döngü ve } \\
72^{\circ} \mathrm{C} 5 \mathrm{dk}\end{array}$ & $\begin{array}{l}\text { Yu ve ark., } \\
2000\end{array}$ \\
\hline & SU91/B8 & $\begin{array}{l}\text { 5'-CCACATCGGTTAACATGAGT-3' } \\
\text { 5'-CCACATCGGTGTCAACGTGA-3' }\end{array}$ & 700 & $\begin{array}{l}94^{\circ} \mathrm{C} 10 \mathrm{~s}, 58^{\circ} \mathrm{C} 40 \mathrm{~s} \\
72^{\circ} \mathrm{C} 2 \mathrm{dk} 34 \text { döngü ve } \\
72^{\circ} \mathrm{C} 5 \mathrm{dk}\end{array}$ & $\begin{array}{l}\text { Pedraza ve } \\
\text { ark., } 1997\end{array}$ \\
\hline \multirow{4}{*}{$\begin{array}{l}\text { Uromyces } \\
\text { appendiculatus }\end{array}$} & SA14/Ur-4 & $\begin{array}{l}\text { 5'-CTATCTGCCATTATCAACTCAAAC-3' } \\
\text { 5'-GTGCTGGGAAACATTACCTATT-3' }\end{array}$ & $1079 / 800$ & $\begin{array}{l}94^{\circ} \mathrm{C} 5 \mathrm{dk} ; 94^{\circ} \mathrm{C} 60 \mathrm{~s}, \\
55^{\circ} \mathrm{C} 60 \mathrm{~s}, 72^{\circ} \mathrm{C} 90 \mathrm{~s} 35 \\
\text { döngü ve } 72^{\circ} \mathrm{C} 5 \mathrm{dk}\end{array}$ & $\begin{array}{l}\text { Mienie ve } \\
\text { ark., } 2004\end{array}$ \\
\hline & SI19/Ur-5 & $\begin{array}{l}\text { 5'-AATGCGGGAGTTCAATAGAAAAACC-3' } \\
\text { 5'-AATGCGGGAGATATTAAAAGGAAAG-3' }\end{array}$ & 460 & $\begin{array}{l}94^{\circ} \mathrm{C} 3 \mathrm{dk} ; 94^{\circ} \mathrm{C} 60 \mathrm{~s}, \\
50^{\circ} \mathrm{C} 60 \mathrm{~s}, 72^{\circ} \mathrm{C} 60 \mathrm{~s} 34 \\
\text { döngü ve } 72^{\circ} \mathrm{C} 7 \mathrm{dk}\end{array}$ & $\begin{array}{l}\text { Souza ve ark., } \\
2007 a\end{array}$ \\
\hline & SBC6/Ur-6 & $\begin{array}{l}\text { 5'-GAAGGCGAGAAGAAAAAGAAAAAT-3' } \\
\text { 5'-GAAGGCGAGAGCACCTAGCTGAAG-3' }\end{array}$ & 308 & $\begin{array}{l}95^{\circ} \mathrm{C} 2 \mathrm{dk} ; 94^{\circ} \mathrm{C} 30 \mathrm{~s}, \\
59^{\circ} \mathrm{C} 60 \mathrm{~s}, 72^{\circ} \mathrm{C} 2 \mathrm{dk} \\
30 \text { döngü ve } 72^{\circ} \mathrm{C} 5 \mathrm{dk}\end{array}$ & $\begin{array}{l}\text { Park ve ark., } \\
2004\end{array}$ \\
\hline & SAE19/Ur-11 & $\begin{array}{l}\text { 5'-CAGTCCCTGACAACATAACACC-3' } \\
\text { 5'-CAGTCCCTAAAGTAGTTTGTCCCTA-3' }\end{array}$ & 890 & $\begin{array}{l}94^{\circ} \mathrm{C} 5 \mathrm{dk} ; 94^{\circ} \mathrm{C} 15 \mathrm{~s}, \\
58^{\circ} \mathrm{C} 60 \mathrm{~s}, 72^{\circ} \mathrm{C} 90 \mathrm{~s} 35 \\
\text { döngü ve } 72^{\circ} \mathrm{C} 5 \mathrm{dk}\end{array}$ & $\begin{array}{l}\text { Alzate-Marin } \\
\text { ve ark., 2004; } \\
\text { De Queiroz } \\
\text { ve ark., } 2004\end{array}$ \\
\hline
\end{tabular}

\section{BULGULAR VE TARTIŞMA}

Fasulye bitkisinde pas hastalı̆̆ına neden olan Uromyces appendiculatus gösterdiği yüksek genetik ve patojenik varyasyondan dolayı mücadelesi en zor patojenlerden bir tanesidir (Tugume ve ark., 2019). Bu kapsamda etmenle mücadelede en etkili yöntem, tek bir gen veya çok sayıda genin bir araya getirilerek oluşturulan gen kombinasyonları taşıyan bitkilerin seçimi ve bunların ıslah materyallerine aktarılmasıdır (Souza ve ark., 2013). Yapılan çalışmalarda fasulye genomunda pasa karşı dayanıkıııkla ilişkili çok sayıda moleküler markör geliştirilmiş ve farklı araştııııılar tarafından ıslah çalışmalarında kullanılmıştır (Haley ve ark., 1993; Johnson ve ark., 1995; Carvalho ve ark., 1998; Freyre ve ark., 1998; Sartorato ve ark., 1999; Miklas ve ark., 2002, 2006; Kelly ve ark., 2003). Benzer şekilde bakteriyel etmenler arasında Xanthomonas axonopodis pv. phaseoli fasulye üretim alanlarında en fazla görülen etmenlerden bir tanesi olup mücadelesi oldukça sınırlıdır (Belete ve Bastas, 2017). Bu nedenle söz konusu etmenlere karşı mücadelede etkin rol oynayan gen kaynaklarının tespiti ve dayanıklı ılah materyallerinin geliştirilmesi büyük önem taşımaktadır. Ancak ülkemizdeki fasulye çeşitlerinin her iki hastalık etmenine karşı dayanıklıık durumları hakkında literatürde sınırlı sayıda çalışma mevcuttur (Dursun ve ark., 2002; Poyraz ve ark., 2017; Yeken ve ark., 2019).

Bu çalışma kapsamında ülkemizde yaygın olarak yetiştirilen 40 fasulye çeşidinin yine ülkemizde oldukça önemli ekonomik kayıplara yol açan pas ve adi yaprak yanıklığı hastalıklarına karşı taşıdıkları dayanıklıık kaynakları moleküler markörler aracılığıyla belirlenmiştir. Fasulye pasına karşı dayanıklııkta rol oynayan 4 farklı geni tespit etmek amacıyla kullanılan markörler arasında SBC6 primeri hariç diğer tüm primerlerden beklenen büyüklükte 
Palacıoğlu ve ark., Ülkemizde Yetiştirilen Önemli Fasulye Çeşitlerinin Pas (Uromyces appendiculatus) ve Adi Yaprak Yanıklığı (Xanthomonas axonopodis pv. phaseoli) Hastalıklarına Karşı Dayanıklılık Kaynakları Açısından Değerlendirilmesi

amplifikasyon ürünü elde edilmiştir (Şekil 1). SA14 primeri ile Ur-4 gen lokusu taranmış ve hassasiyet/dayanıklılık ile ilişkili 1079-800 bp büyüklüğünde amplifikasyon ürünleri elde edilmiştir. Test sonucunda 800 bp büyüklüğünde amplifikasyon ürünü elde edilen Perolar, Sofia ve Akdağ fasulye çeşitleri hassas olarak değerlendirilirken diğer tüm çeşitlerin 1079 bp büyüklüğünde PCR ürünü çoğaltarak Ur-4 dayanıklılık genini taşıdığı görülmüştür. Ur-5 geni ile ilişkili olan ve 460 bp büyüklüğünde ürün veren SI19 primeri Cornell referans genotipi dışında diğer hiçbir çeşitte PCR ürünü vermemiştir. SAE19 primeri ile Ur-11 gen lokusu taranmış ve tüm çeşitlerin Ur-11 genine sahip olduğu tespit edilmiştir. Genel olarak 40 fasulye çeşidinin U. appendiculatus'a karşı dayanıklılık kaynaklarını incelediğimizde tüm çeşitlerin Ur-11 geni taşıdığı, Sofia, Perolar ve Akdağ dışındaki diğer çeşitlerin Ur-4 genine sahip olduğu, Ur-5 geninin ise hiçbir çeşitte görülmediği tespit edilmiştir. Mienie ve ark. (2004) yaptıkları çalışmada, 1079 bp büyüklüğünde ürün amplifiye eden BelMiDak-RR-9 ve BelMiDak-RMR-11 çeşitlerinin dayanıklılık alleli taşıdığını, elNeb-RR 1 ve Teebus çeşitlerinin ise 800 bp PCR ürünü amplifiye ederek hassaslık ile ilgili alleli taşıdığını bildirmişlerdir. Yaptığımız çalışmada da Mienie ve ark. (2004) ile uyumlu sonuçlar elde edilmiş olup 37 çeşit ve USDA'dan elde edilen TO genotipinde 1079 bp büyüklüğünde PCR ürünü amplifiye edilerek bu çeşitlerin Ur-4 geni ile ilişkili dayanıklı alleli taşıdığı belirlenmiştir. Souza ve ark. (2007a) Sı19 markörünün çeşitler arasında polimorfik olduğunu ve Ur-ON ve Ur-11 genlerini taşıyanlardan ayırt edilebildiğini bildirmiştir. Bu kapsamda Ur-5 geni amplikon büyüklüğü ile diğer genlerden ayırt edilebilmiş ve Souza ve ark. (2007a) ile benzer sonuçlar elde edilmiştir. Ayrıca test edilen fasulye çeşitlerinden Ur-4 genine sahip olanların hiçbirinin Ur-5 genini taşımadığı tespit edilmiştir. Benzer şekilde ülkemizdeki 43 fasulye çeşidinin pas hastalığına karşı dayanıkılık kaynaklarını 4 farklı markör ile araştıran Yeken ve ark. (2019), 27 çeşidin Ur-4 geni taşıdığı ancak Ur-5 geninden yoksun olduğunu belirtmiştir.

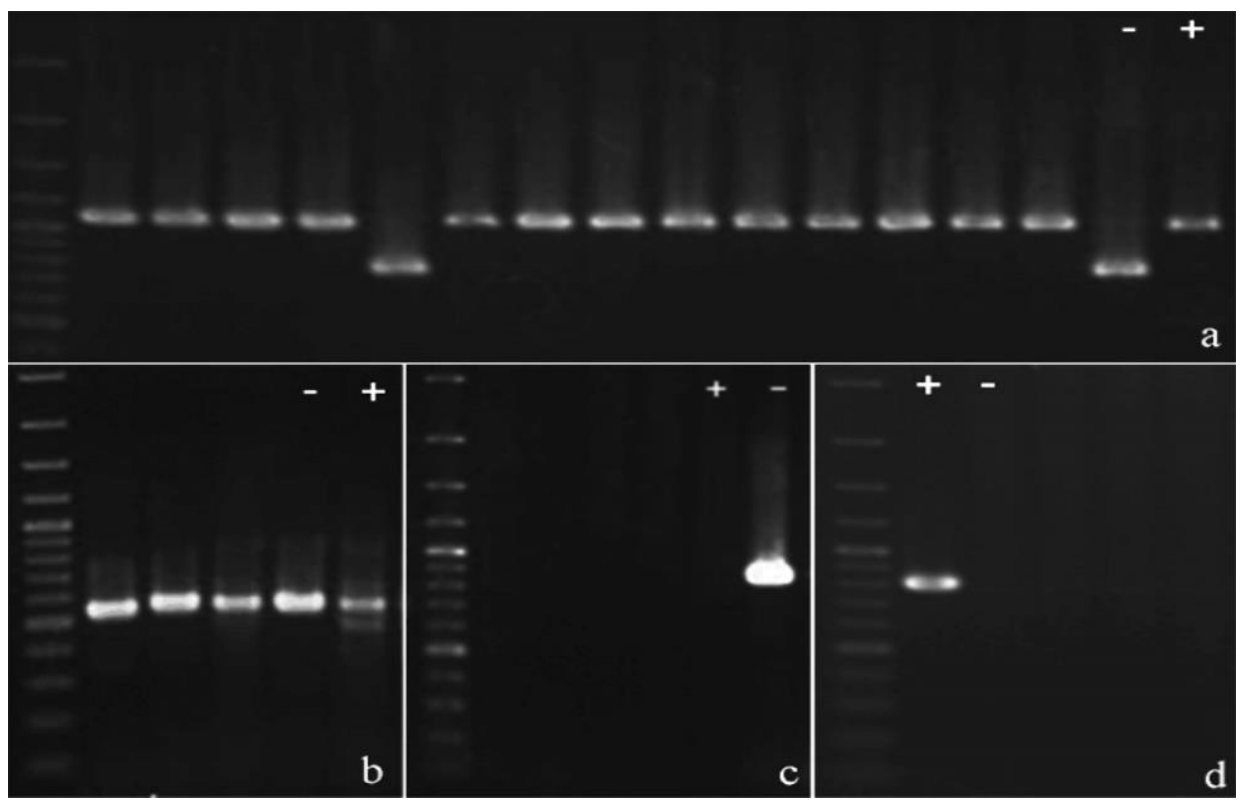

Şekil 1. Fasulye bitkisinde pas ve adi yaprak yanıklığı hastalığına karşı dayanıklılıkla ilişkili genlerin PCR amplifikasyonu. (a: Ur4 geninin SA14 markörü ile amplifikasyonu sonucu elde edilen jel görüntüsü, 800 bp/hassas-Cornell (-); 1079 bp/dayanıklı-To (+), b: Ur-5 geninin SI19 markörü ile amplifikasyonu sonucu elde edilen jel görüntüsü Cornell (+), To (-), C: Ur-11 geninin SAE19 markörü ile amplifikasyonu sonucu elde edilen spesifik PCR ürünü, Ouro negro (-), d: B10 lokusu ile ilişkili SAP6 primeri ile elde edilen spesifik PCR ürünü, Widusa (+), Cornell (-). Markör: GeneRuler 100 bp DNA ladders, Thermo Scientific).

Figure 1. PCR amplifications of genes associated with resistance to rust and common bacterial blight in common bean (a: Gel image showing the amplification of the Ur-4 gene with SA14 marker, 800 bp/susceptible-Cornell (-), 1079 bp/resistant-To (+), $b$ : Gel image showing the amplification of Ur-5 gene with S/19 marker, Cornell (+), To (-), c: Specific PCR product obtained by amplification of Ur-11 gene with SAE19 marker, Ouro negro (-), d: Specific PCR product obtained with SAP6 primer associated with $B 10$ locus, Widusa (+), Cornell (-). Marker: GeneRuler 100 bp DNA ladders, Thermo Scientific).

De Queiroz ve ark. (2004), Belmidak RR-3 ve Ruda (Dayanıklı-Hassas) çeşitlerini Ur-11 geniyle ilişkili SAE19 primeri ile araştırmış ve amplifikasyon ürünü oluşturmayan bitkileri dayanıklı, beklenen büyüklükte PCR ürünü elde edilen bireyleri hassas olarak değerlendirmiştir. Alzate-Marin ve ark. (2004) ise Ouro negro dayanıklılık geni ile Ur-5 ve Ur-11 gen allelleri arasındaki ilişkiyi değerlendirmiş ve Ouro negro dayanıklıık geninin diğer iki allelden farklı olduğunu bildirmiştir. Yaptığımız çalışmada SAE19 primeri ile sadece Ouro negro çeşidinde PCR ürünü elde edilmiş ve Ouro negro referansının Ur-11 geninden yoksun olduğu değerlendirilmiştir. Alzate-Marin ve ark. (2004) Ur-5, Ur- 11 ve Ouro negro dayanıklılık genlerinin birleşimi ile oluşturulan gen piramidinin dünya çapındaki pas ırklarına karşı etkili bir direnç sağlayacağını belirtmiştir. Ancak ülkemizdeki test edilen fasulye çeşitlerinin tamamı 
Palacıoğlu ve ark., Ülkemizde Yetiştirilen Önemli Fasulye Çeşitlerinin Pas (Uromyces appendiculatus) ve Adi Yaprak Yanıklığı (Xanthomonas axonopodis pv. phaseoli) Hastalıklarına Karşı Dayanıklılık Kaynakları Açısından Değerlendirilmesi

Ur-11 genine sahipken, hiçbirinin Ur-5 geni taşımadığı tespit edilmiştir. Bu nedenle Ouro negro gibi farklı dayanıklılık genlerinin araştırımasının ıslah çalışmalarına fayda sağlayacağı düşünülmektedir.

Adi yaprak yanıklığına karşı dayanıklılık kaynaklarını tespit etmek amacıyla yapılan PCR çalışmalarında ise BC420 ve SU91 primerlerinden herhangi bir amplifikasyon ürünü elde edilemezken, SAP6 markörü ile beklenen büyüklükte PCR ürünü elde edilmiştir (Şekil 1). Test edilen çeşitler arasında Boncuk, Belinay Sırık, Sırık Barbunya, Zülbiye, Bulduk çeşitlerinde ve Widusa referansında 820 bp büyüklügünde ürün elde edilerek B10 lokusunun varlığı belirlenmiştir. Benzer şekilde Poyraz ve ark. (2017) ülkemizdeki 12 fasulye çeşidinin X. axonopodis pv. phaseoli'ye karşı dayanıkııık genlerini 6 farklı SCAR markör ile araştırdıkları çalışmada, sadece Berly ve Yunus-90 çeşitlerinin SAP6 markörü ile ilişkili B10 lokusunu taşıdığını bildirmiştir. Mutlu ve ark. (2005) QTL bölgeleri ile ilişkili moleküler markörler yardımıyla geri melezleme ile elde ettikleri bireylerde adi yaprak yanıklığına karşı dayanıkııık kazanma durumlarını inceledikleri çalışmada, dayanıklı olan 3 gelişmiş hattın ( NE-01-8, NE-01-15, NE-01-17) SU91 ile ilişkili B8 ve SAP6 ile ilişkili B10 lokusuna sahip olduğunu bildirmiştir. Araştırıcılar aynı zamanda SAP6 ve SU91 dayanıklılık markörlerini kullanarak dayanıklı Chase ve hassas Othello çeşitlerinin çaprazlanmasıyla adi yaprak yanıklığına karşı daha fazla dayanıklılık gösteren ABCP-8 genotipini geliştirmiştir.

\section{SONUÇ}

Bu çalışma kapsamında elde edilen sonuçlar genel olarak değerlendirildiğinde incelenen fasulye çeşitlerinin büyük çoğunluğunun pas hastalığına karşı etkili olan Ur-4 ve Ur-11 genlerini taşıdığı, Boncuk, Belinay Sırık, Sırık Barbunya, Zülbiye ve Bulduk çeşitlerinin ise adi yaprak yanıklığına karşı dayanıkılıkta rol olan B10 lokusuna sahip olduğu gözlenmiştir. Elde edilen sonuçlar yaygın olarak yetiştirilen fasulye çeşitlerindeki dayanıklılık kaynaklarının belirlenmesinde moleküler markörlerin etkinliğini ortaya koymaktadır. Bu kapsamda ülkemizdeki diğer çeşit ve köy popülasyonlarındaki dayanıklılık kaynaklarının hızlı ve etkin bir şekilde belirlenmesinde bu markörlerin kullanılabileceği düşünülmektedir. Ayrıca fasulye bitkisinde adi yaprak yanıklığı ve pasa karşı dayanıklılık genleri içeren bu çeşitlerin ıslah çalışmalarında önemli birer genetik kaynak sağlayacağı düşünülmektedir. Ancak ülkemizdeki yerel fasulye genotiplerindeki farklı dayanıklılık kaynaklarının belirlenmesine yönelik detaylı çalışmaların yapılmasının ülkemiz fasulye yetiştiriciliğinde sorun bu hastalıklarla mücadele çalışmaları açısından oldukça önem taşıyacağı düşünülmektedir.

\section{ÇIKAR ÇATIŞMASI BEYANI}

Yazarlar arasında herhangi bir çıkar çatışması bulunmamaktadır.

\section{YAZAR KATKI BEYANI}

GP ve ST çalışmanın yürütülmesinde, $\mathrm{HB}$ ve $\mathrm{GÖ}$ çalışmanın planlanması ve makalenin yazımında katkıda bulunmuşlardır.

\section{KAYNAKLAR}

Altıkardeşler, A., \& Arslan, Ü. (2007). Fasulye (Phaseolus vulgaris L.) çeşitlerinin pas hastalığı (Uromyces appendiculatus (Pers.: Pers.) Unger)'na karşı reaksiyonları ve bazı fungisitlerin etkisi. Journal of Agricultural Faculty, 21(1), 1-8.

Alzate-Marin, A. L., Souza, T. L. P. O., Ragagnin, V. A., Moreira, M. A., \& Barros, E. G. (2004). Allelism tests between the rust resistance gene present in common bean cultivar Ouro Negro and genes Ur-5 and Ur-11. Journal of Phytopathology, $152,60-64$.

Araya, C. M., Alleyne, A. T., Steadman, J. R., Eskridge, K. M., \& Coyne, D. P. (2004). Phenotypic and genotypic characterization of Uromyces appendiculatus from Phaseolus vulgaris in the Americas. Plant Disease, 88(8), 830-836.

Belete, T., \& Bastas, K. K. (2017). Common bacterial blight (Xanthomonas axonopodis pv. phaseoli) of beans with special focus on Ethiopian condition. Journal of Plant Pathology and Microbiology, 8(2), 1000403.

Broughton, W. J., Hernandez, G., Blair, M., Beebe, S., Gepts, P., \& Vanderleyden, J. (2003). Beans (Phaseolus spp.)-model food legumes. Plant and Soil, 252(1), 55-128.

Carvalho, G. A. D., Paula Junior, T. J., Alzate-Marin, A. L., Nietsche, S., Barros, E. D., \& Moreira, M. A. (1998). Herança da resistência da linhagem AND-277 de feijoeiro-comum à raça 63-23 de Phaeoisariopsis griseola e identificação de marcador RAPD ligado ao gene de resistência. Fitopatologia Brasileira, 23, 482-485. 
Palacıoğlu ve ark., Ülkemizde Yetiştirilen Önemli Fasulye Çeşitlerinin Pas (Uromyces appendiculatus) ve Adi Yaprak Yanıklığı (Xanthomonas axonopodis pv. phaseoli) Hastalıklarına Karşı Dayanıklılık Kaynakları Açısından Değerlendirilmesi

De Queiroz, V. T., de Sousa, C. S., De Souza, T. L. P. O., Sanglard, D. A., Ragagnin, V. A., de Barros, E. G., \& Moreira, M. A. (2004). SCAR marker linked to the common bean rust resistance gene Ur-11. Annual Report.

Dursun, A., Dönmez, M. F., \& Şahin, F. (2002). Identification of resistance to common bacterial blight disease on bean genotypes grown in Turkey. European Journal of Plant Pathology, 108(8), 811-813.

Edington, B. R., Shanahan, P. E., \& Rijkenberg, F. H. J. (1994). Breeding for partial resistance in dry beans (Phaseolus vulgaris) to bean rPha (Uromyces appendiculatus). Annals of Applied Biology, 124, 341-350.

Faleiro, F. G., Vinhadelli, W. S., Ragagnin, V. A., Corrêa, R., Moreira, M. A., \& Barros, E. G. (2000). RAPD markers linked to a block of genes conferring rust resistance to the common bean. Genetics and Molecular Biology, 23, 399-402.

FAOSTAT. (2020). Food and Agriculture Organization of the United Nations. http://www.fao.org/faostat/en/\#data/QC. Erişim tarihi: 23 Aralık 2020.

Freyre, R., Skroch, P. W., Geffroy, V., Adam-Blondon, A. F., Shirmohamadali, A., Johnson, W. C., Llaca, V., Nodari, R. O., Pereira, P. A., Tsai, S. M., Tohme, J., Dron, M., Nienhuis, J., Vallejos, C. E., \& Gepts, P. (1998). Towards an integrated linkage map of common bean. 4.Development of a core linkage map and alignment of RFLP maps. Theoretical and Applied Genetics, $97,847-856$.

Gillard, C. L., Conner, R. L., Howard, R. J., Pauls, K. P., Shaw, L., \& Taran, B. (2009). The performance of dry bean cultivars with and without common bacterial blight resistance in field studies across Canada. Canadian journal of plant science, 89(2), 405-410.

Grafton, K. F., Weiser, G. C., Littlefield, L. J., \& Stavely, J. R. (1985). Inheritance of resistance to two races of leaf rust in dry edible bean. Crop Science, 25, 537-539.

Haley, S. D., Miklas, P. N., Stavely, J. R., Byrum, J., \& Kelly, J. D. (1993). Identification of RAPD markers linked to a major rust resistance gene block in common bean. Theoretical and Applied Genetics, 86(4), 505-512.

Hall, R. (1994). Bean diseases, bean pathogens, bean disease control. Compendium of Bean Diseases, APS press, Minnesota, USA.

Johnson, E., Miklas, P. N., Stavely, J. R., \& Martinez-Cruzado, J. C. (1995). Coupling-and repulsion-phase RAPDs for markerassisted selection of PI 181996 rust resistance in common bean. Theoretical and Applied Genetics, 90(5), 659-664.

Jung, G., Coyne, D. P., Skroch, P., Nienhuis, J., Arnaud-Santana, E., Bokosi, J., Ariyarathne, H., Steadman, J., Beaver, J., \& Kaeppler, S. (1996). Molecular markers associated with plant architecture and resistance to common blight, web blight, and rust in common beans. Journal of the American Society for Horticultural Science, 121, 794-803.

Kelly J. D., Gepts, P., Miklas, P. N., \& Coyne, D. P. (2003). Tagging and mapping of genes and QTL and molecular-marker assisted selection for traits of economic importance in bean and cowpea. Field Crops Research, 82, 135-154.

Liebenberg, M. M., Mienie, C. M. S., \& Pretorius, A. Z. (2006). The occurrence of rust resistance gene Ur-13 in common bean cultivars and lines. Euphytica, 150, 365-386.

Lindgren, D. T., Eskridgre, K. M., Steadman, J. R., \& Schaaf, D. M. (1995). A model for dry bean yield loss due to rust. HortTechhnology, 5, 35-37.

McClean, P., \& Myers, J. (1990). Pedigrees of dry bean cultivars, lines and PIs. Annual Report of the Bean Improvement Cooperative, 33, 25-30.

Mienie, C. M. S., Naidoo, R., \& Liebenberg, M. M. (2004). Conversion of the RAPD Marker for Ur-4 to a Co-Dominant SCAR Marker SA 14 1 0 7 9 / 8 0 0. Annual Report-Bean Improvement Cooperative, 47, 261-262.

Miklas, P. N., Kelly, J. D., Beebe, S. E., \& Blair, M. W. (2006). Common bean breeding for resistance against biotic and abiotic stresses:from classical to MAS breeding. Euphytica, 147, 105-131.

Miklas, P. N., Pastor-Corrales, M. A., Jung, G., Coyne, D. P., Kelly, J. D., McClean, P. E., \& Gepts, P. (2002). Comprehensive linkage map of bean rust resistance genes. Annual Report of the Bean Improvement Cooperative, 45, 125-129.

Miklas, P. N., Stone, V., Daly, M. J., Stavely, J. R., Steadman, J. R., Bassett, M. J., Delorme, R., \& Beaver, J. S. (2000). Bacterial, fungal, and viral disease resistance loci mapped in a recombinant inbred common bean population (Dorado/XAN 176). Journal of the American Society for Horticultural Science, 125, 476-481.

Mutlu, N., Miklas, P., Reiser, J., \& Coyne, D. (2005). Backcross breeding for improved resistance to common bacterial blight in pinto bean (Phaseolus vulgaris L.). Plant Breeding, 124(3), 282-287.

Park, S. O., Coyne, D. P., Steadman, J. R., Crosby, K. M., \& Brick, M. A. (2004). RAPD and SCAR markers linked to the Ur-6 Andean gene controlling specific rust resistance in common bean. Crop Science, 44(5), 1799-1807. 
Palacıoğlu ve ark., Ülkemizde Yetiştirilen Önemli Fasulye Çeşitlerinin Pas (Uromyces appendiculatus) ve Adi Yaprak Yanıklığı (Xanthomonas axonopodis pv. phaseoli) Hastalıklarına Karşı Dayanıklılık Kaynakları Açısından Değerlendirilmesi

Pastor-Corrales, M. A., Pereira, A. P. A., Lewers, K., Brondani, R. V., Buso, G. C., Ferreira, M. A., \& Martins, W. S. (2008). Identification of SSR markers linked to rust resistance in Andean common bean PI 260418. Annual Report of the Bean Improvement Cooperative, 51, 46-47.

Pastor-Corrales, M. A. (2005). Inheritance of resistance in PI260418 an Andean bean resistant to most races of the bean rust pathogen. Annual Report of the Bean Improvement Cooperative, 48, 134-135.

Pedraza, F., Gallego, G., Beebe, S., \& Tohme, J. (1997). Marcadores SCAR y RAPD para la resistencia a la bacteriosis comun (CBB). Taller de mejoramiento de frijol para el Siglo XXI: Bases para una estrategia para America Latina, 130-134.

Poyraz, İ., Şahin, B., \& Atmaca, E. (2017). Detection of Ten Resistance Genes Against $P$. syringae pv. phaseolicola and $X$. axonopodis pv. phaseoli in Twelve Local Bean Varieties Using SCAR Markers. Iğdır Üniversitesi Fen Bilimleri Enstitüsü Dergisi, 7(2), 241-248.

Rasmussen, J. B., Grafton, K. F., Gross, P. L., \& Donohue, C. M. (2002). Genetics of rust resistance in Compuesto Negro Chilmaltenango (CNC). Annual Report of the Bean Improvement Cooperative, 45, 94-95.

Sartorato, A., Nietsche, S., Barros, E. G, \& Moreira, M. A. (1999). Inheritance of angular leaf spot resistance and RAPD markers linked to disease resistance gene in common beans. Annual Report of the Bean Improvement Cooperative, 42, 21-22.

Souza, T. L. P. O., Dessaune, S. N., Sanglard, D. A., Moreira, M. A., \& Barros, E. G. (2007a). Rust resistance gene present in common bean cultivar Ouro Negro (Ur-ON) does not correspond to Ur-3+. Annual Report of the Bean Improvement Cooperative, 50, 119-120.

Souza, T. L. P. O., Alzate-Marin, A. L., Dessaune, S. N., Nunes, E. S., Queiroz, V. T., Moreira, M. A., \& Barros, E. G. (2007b). Inheritance study and validation of SCAR molecular marker for rust resistance in common bean. Crop Breeding and Applied Biotechnology, 7, 11-15.

Souza, T. L. P. O., Alzate-Marin, A. L., Faleiro, F. G., \& Barros, E. G. (2008). Pathosystem common bean-Uromyces appendiculatus: host resistance, pathogen specialization, and breeding for rust resistance. Pest Technology, 2, 56-69.

Souza, T. L. P., Faleiro, F. G., Dessaune, S. N., Paula-Junior, T. J. D., Moreira, M. A., \& Barros, E. G. D. (2013). Breeding for common bean (Phaseolus vulgaris L.) rust resistance in Brazil. Tropical Plant Pathology, 38(5), 361-374.

Stavely, J. R., \& Grafton, K. F. (1985). Genetics of resistance to eight races of Uromyces appendiculatus in Phaseolus vulgaris cultivar Mexico 235. Phytopathology, 75, 1310.

Tugume, J. K., Tusiime, G., Sekamate, A. M., Buruchara, R., \& Mukankusi, C. M. (2019). Diversity and interaction of common bacterial blight disease-causing bacteria (Xanthomonas spp.) with Phaseolus vulgaris L. The Crop Journal, 7(1), 1-7.

TÜIK. (2019). Türkiye İstatistik Kurumu, Bitkisel Üretim İstatistikleri. http://www.tuik.gov.tr. Erişim tarihi 20 Aralık 2020.

Yeken, M. Z., Özer, G., Çelik, A., \& Çiftçi, V. (2019). Tescilli Fasulye Çeşitlerinin Pas (Uromyces appendiculatus) Etmenine Karşı Dayanıklılık Durumlarının SCAR Markörleri ile Belirlenmesi. Türk Tarım ve Doğa Bilimleri Dergisi, 6(3), 410-416.

Yeken, M. Z., Kantar, F., Çancı, H., Özer, G., \& Çiftçi, V. (2018). Breeding of dry bean cultivars using Phaseolus vulgaris landraces in Turkey. International Journal of Agricultural and Wildlife Sciences, 4(1), 45-54.

Yu, K., Park, S. J., \& Poysa, V. (2000). Marker-assisted selection of common beans for resistance to common bacterial blight: efficiency and economics. Plant Breeding, 119, 411-416.

Zaiter, H. Z., Coyne, D. P., \& Steadman, J. R. (1989). Inheritance of resistance to a rust isolate in beans. Annual Report of the Bean Improvement Cooperative, 32, 126-127. 